Sean Kelly, professor, political science, California State University, Channel Islands, will be one of 10 scholars serving on the Dirksen Congressional Center's National Advisory Council, a national council designed to help Americans get a deeper understanding of how the US Congress works.

Daniel T. Kirsch, associate professor of political science, Valley Forge Military College in Wayne, Pennsylvania.

Sergei Kostiaev, acting deputy chair of the department of applied political science, Financial University in Moscow, Russia.

\section{AWARDS}

Christopher Alcantara, associate professor, department of political science, Wilfrid Laurier University, has been awarded the 2014 International Council for Canadian Studies Pierre Savard Award and the 2014 Canadian Studies Network-Réseau d'études canadiennes Prize for the best book in Canadian studies. The winning book, entitled Negotiating the Deal: Comprehensive Land Claims Agreements in Canada (University of Toronto Press), was also a finalist last year for the Canadian Political Science Association's Donald Smiley Prize.

David Fott, professor of political science at the University of Nevada, Las Vegas, has received the William Morris Award for Excellence in Scholarship in the social sciences from the UNLV College of Liberal Arts.

John Gould, professor of political science, Colorado College, has been named a 2016 Fulbright Scholar and will travel to Slovakia to research the politics of nationalism and sexual minorities in that country and beyond. He also will teach at the Institute of European Studies and International Relations at Comenius University.

Ravi Perry, an assistant professor in political science at Mississippi State University, was recognized as a 2015 Hero Citizen by The Andrew Goodman Foundation in January.
Carsten Vala, associate professor, Loyola University, Maryland, has been awarded a grant through the Core US Fulbright Scholar Program to study the politics of China's rapidly growing investment in Latin America, with a specific focus on China's influence on the copper industry in Chile. Vala will travel to Chile for his research from August to December 2015. During that time he will also teach two courses on Chinese politics and Chinese globalization at Pontificia Universidad Católica de Chile in Santiago and offer public presentations on the contemporary politics of China.

Christian Welzel, chair, political culture research, Center for the Study of Democracy, Leuphana University, received both the Stein Rokkan Prize (awarded by the European Consortium of Political Research) and the Alexanxder L. George Award (awarded by the International Society of Political Psychology) for his monograph Freedom Rising: Human Empowerment and the Quest for Emancipation (Cambridge University Press 2013).

\title{
Members among New Andrew Carnegie Fellows
}

Political scientists and APSA members represent more than a third of the 32 Andrew Carnegie Fellows of the inaugural class of a major annual fellowship program. Their proposals address issues including policing and race, big data and privacy, the impact of an aging population, and how attitudes are formed among voters.

Susan Hockfield, MIT President Emerita, who chaired the selection jury, said, "What impressed me most was the quality of the proposals-they seek to tackle some of the most pressing issues of our times with innovative and forward-looking ideas from a wide range of high-caliber candidates. Solutions to the complex issues of today and tomorrow will not emerge simply through technology and science, but require humanistic and social science scholarship to use lessons of the past to devise paths to future peace and progress."

The 13 political scientists listed below are established and emerging scholars who are researching a wide variety of compelling and critical issues. Each fellow's name and research topic is listed along with a short summary of professional achievements. For a full listing, visit http://carnegie.org/news/grantee-news/andrew-carnegie-fellows-2015/.

\section{LARRY M. BARTELS, VANDERBILT} UNIVERSITY

\section{Political Inequality in Affluent} Democracies: The US in Comparative Perspective

Larry M. Bartels holds the May Werthan Shayne Chair of Public Policy and Social Science at Vanderbilt University. His scholarly work focuses broadly on American democracy, including public opinion, electoral politics, public policy, and political representation. An award winning author, his most recent book is Mass Politics in Tough Times (Oxford University Press, 2014, coedited with Nancy
Bermeo). His next book, coauthored with Christopher Achen, is titled Democracy for Realists.

Bartels was educated at Yale University (BA, MA) and the University of California, Berkeley (PhD). He has served as vice president of the APSA Council and president of the Political Methodology Section, chair of the Board of Overseers of the American National Election Studies, and founding director of Princeton University's Center for the Study of Democratic Politics. In 2014 he received the Warren E. Miller Prize for an outstanding career of intellectual accom- plishment and professional service in the field of elections, public opinion, and voting behavior. He is a member of the American Academy of Arts and Sciences, the American Academy of Political and Social Science, and the National Academy of Sciences.

FOTINI CHRISTIA, MASSACHUSETTS INSTITUTE OF TECHNOLOGY

Gauging Shi'a Public Opinion towards Conflict in the Middle East

Fotini Christia is an associate professor of political science at MIT working on issues of conflict and development in the Muslim 
world. She has carried out extensive ethnographic, survey, and experimental fieldwork within Afghanistan and Bosnia and is currently working on projects on security and governance in Yemen and South Iraq. Her articles have been published in Science, the American Political Science Review, and Comparative Politics among other journals, and she has written essays and opinion pieces for Foreign Affairs, the New York Times, and the Washington Post. Her book, Alliance Formation in Civil Wars, published by Cambridge University Press, received the Luebbert award for best book in comparative politics, the Lepgold prize for best book in international relations, and the distinguished book award of the ethnicity, nationalism, and migration section of the International Studies Association. Fotini received her $\mathrm{PhD}$ in public policy from Harvard University in 2008, her MA in international affairs from Columbia University in 2001, and her BA in economics and operations research from Columbia College in 2000.

\section{JOHN D. CIORCIARI, UNIVERSITY OF MICHIGAN}

\section{The United Nations and Shared Sovereignty in Weak or Transitional States}

John D. Ciorciari is an assistant professor at the Gerald R. Ford School of Public Policy at the University of Michigan. He currently codirects the Ford School's International Policy Center, serves on the board of the Human Rights Initiative at the University's International Institute, and is a faculty affiliate of the Center for Southeast Asian Studies. His research and teaching focus on international law and politics. He is the coauthor of Hybrid Justice: The Extraordinary Chambers in the Courts of Cambodia (University of Michigan Press, 2014) and author of The Limits of Alignment: Southeast Asia and the Great Powers since 1975 (Georgetown University Press, 2010). He has also published in numerous academic journals on topics including international security, multilateral institutions, international criminal law, human rights, Asian politics, and US foreign policy. He is an associate fellow at the Asia Society, term member of the Council on Foreign Relations, and senior legal advisor to the Documentation Center of Cambodia. $\mathrm{He}$ holds an AB from Harvard College in biochemistry, a JD from Harvard Law School, and an M.Phil. and D.Phil. in international relations from Oxford, where he was a Fulbright Scholar.
DONALD P. GREEN, COLUMBIA UNIVERSITY

\section{Changing Minds on Divisive Social Issues}

Donald P. Green is professor of political science at Columbia University. The author of four books and more than one hundred scholarly articles, Green's research interests span a wide array of topics: voting behavior, partisanship, campaign finance, hate crime, and research methods. Much of his current work uses field experimentation to study the ways in which political campaigns mobilize and persuade voters, and he is credited with several important substantive and methodological contributions. Prior to joining the faculty at Columbia University, Green taught at Yale University (1989-2011), where he was A. Whitney Griswold Professor of Political Science and served five terms as director of Yale's Institution for Social and Policy Studies. He was elected to the American Academy of Arts and Sciences in 2003 and has received numerous awards, among them the Heinz I. Eulau Award for best article published in the American Political Science Review. Green is also an accomplished board game inventor. His game OCTI was named Abstract Game of the Year in 2000 by GAMES Magazine.

\section{MALA HTUN, UNIVERSITY OF NEW} MEXICO

\section{Gender Disadvantage, Women's Eco-} nomic Agency, and Global Public Good

Mala Htun is associate professor of political science at the University of New Mexico. Her scholarly work analyzes state actions to expand the opportunities of disadvantaged groups and the consequences for democratic politics and social equality. She is the author of Sex and the State:Abortion, Divorce, and the Family under Latin American Dictatorships and Democracies (Cambridge University Press, 2003) and Inclusion Without Representation: Gender Quotas and Ethnic Reservations in Latin America (forthcoming from Cambridge). In addition to serving on the APSA Council, Htun was coeditor with G. Bingham Powell, Jr. of a recent APSA task force report (Political Science, Electoral Rules, and Democratic Governance found at http://www.apsanet.org/ electoralrules), and her work has appeared in multiple prominent journals and edited volumes.

She has held the Council on Foreign Relations International Affairs Fellowship in Japan, and was a fellow at the Kellogg Institute of the University of Notre Dame and the Radcliffe Institute of Harvard. She has served as a consultant to the World Bank, UN Women, Inter-American Development Bank, and the Inter-American Dialogue. Htun holds a $\mathrm{PhD}$ in political science from Harvard and an $\mathrm{AB}$ in international relations from Stanford, and is a graduate of the Colorado Rocky Mountain School.

\section{VALERIE M. HUDSON, TEXAS A\&M UNIVERSITY \\ Household Formation Systems and National Stability/Security}

Valerie M. Hudson is professor and George H. W. Bush Chair at the Bush School of Government and Public Service at Texas A\&M University. Her research foci include foreign policy analysis, security studies, gender and international relations, and methodology. Hudson is the author or editor of several books, including (with Andrea Den Boer) Bare Branches: The Security Implications of Asia's Surplus Male Population (MIT Press, 2004), which won the multiple awards, resulting in feature stories in the New York Times, The Economist, "6o Minutes," and other news outlets. She served as the Director of Graduate Studies for the David M. Kennedy Center for International and Area Studies for eight years, and served as vice president of the International Studies Association for 2011-2012. Hudson is one of the Principal Investigators of the WomanStats Project, which includes the largest compilation of data on the status of women in the world today. She is also a founding editorial board member of Foreign Policy Analysis, and a current or former editorial board member of Politics and Gender, the American Political Science Review, and the International Studies Review. Hudson's forthcoming 2015 book with Patricia Leidl, also from Columbia University Press, is The Hillary Doctrine: Sex and American Foreign Policy.

\section{MARIA IVANOVA, UNIVERSITY OF MASSACHUSETTS, BOSTON \\ United Nations at a Crossroads: Col- lection of Conventions or Mechanism for Planetary Stewardship}

Maria Ivanova is an international relations and environmental policy scholar specializing in governance and sustainability. She is associate professor of global governance at the John W. McCormack Graduate School of Policy and Global Studies at the University of Massachusetts Boston where she also codirects the Center for Governance and Sustainability.

Her career, marked by teaching excellence and policy leadership, has bridged 
academia and policy. In 2009, Ivanova convened, for the first and only time, all five consecutive executive directors of the UN Environment Programme along with more than 70 other leaders, creating a network of emerging leaders in global environmental governance. In 2013, she was appointed to the UN Secretary-General's Scientific Advisory Board and, in 2014, to the Board of the UN University Institute for the Advanced Study of Sustainability (UNU-IAS).

Ivanova served as coordinating lead author in the Global Environmental Outlook (GEO-5), the flagship UN environmental assessment in 2012. She has numerous publications, has produced short documentaries on global environmental governance, is the founder and editor of the Governance and Sustainability Issue Brief Series and the Global Leadership Dialogues at UMass Boston, and serves on the editorial board of Global Environmental Politics.

\section{KEIR A. LIEBER, GEORGETOWN UNIVERSITY}

\section{Nuclear Weapons and the New Era of Strategic Instability}

Keir A. Lieber is a tenured professor in Georgetown University's Edmund A. Walsh School of Foreign Service, where he is also a core faculty member of the Center for Security Studies and of the Security Studies Program. Lieber also holds a joint appointment with the department of government. His areas of expertise include nuclear weapons, strategy, and deterrence; the causes of war; US foreign policy; and international relations theory. His articles have appeared in the leading scholarly and foreign policy publications, including International Security, Security Studies, Foreign Affairs, and the AtlanticMonthly. He has been awarded major fellowships from the Brookings Institution, Council on Foreign Relations, Earhart Foundation, Naval Postgraduate School, and Smith Richardson Foundation. Lieber is currently writing a book (with Daryl Press of Dartmouth College) on nuclear weapons and international politics. Lieber earned his MA and $\mathrm{PhD}$ in the department of political science at the University of Chicago, graduated Phi Beta Kappa with a BA from the University of Wisconsin, and is a proud product of the Washington, DC public school system.

\section{ARTHUR LUPIA, UNIVERSITY OF MICHIGAN}

\section{Improving the Public Value of Social} Science

Arthur Lupia is the Hal R. Varian Professor of Political Science at the University of
Michigan and research professor at its Institute for Social Research. He examines how people learn about politics and policy, and he conducts research on how to improve science communication. He has published more than 80 articles on learning and decision making. His books include The Democratic Dilemma:Can Citizens Learn What They Need to Know, Elements of Reason: Cognition, Choice, and the Bounds of Rationality, and The Cambridge Handbook of Experimental Political Science. Later in 2015, Oxford University Press will publish his newest book, Uninformed: Why People Know So Little about Politics and What We Can Do about It.

Lupia has developed a range of infrastructure to improve the quality and public value of social scientific research. Recently, he coauthored an APSA task force (forthcoming as a special issue of PS: Political Science and Politics) on pubilc perceptions of social science's value (available at http:// www.apsanet.org/publicperceptions). Lupia is a native of Buffalo, New York. He earned a $\mathrm{PhD}$ in social science from the California Institute of Technology and an undergraduate degree in economics from the University of Rochester.

PATRICIA L. SULLIVAN, UNIVERSITY OF NORTH CAROLINA, CHAPEL HILL Arming the Opposition: Understanding the Long-term Impacts of Providing Lethal Aid to Nonstate Actors

Patricia Sullivan, an award-winning teacher and scholar, is an associate professor of public policy and of peace, war, and defense at the University of North Carolina, Chapel Hill. She earned her $\mathrm{PhD}$ in political science from the University of California, Davis in 2004. Sullivan's research focuses on the utility and limitations of employing military force and providing foreign military assistance to attain policy objectives. Her research has been published in numerous respected academic journals, and she has authored a highly regarded book published by Oxford University Press in 2012, Who Wins? Predicting Strategic Success and Failure in Armed Conflict. Sullivan has been invited to present her research to academic audiences, military officers, and civilian Department of Defense personnel. She is on the Executive Board of the Triangle Institute for Security Studies and the advisory board for the Correlates of War Project. Sullivan teaches courses in national and international security, global policy, and social science research design and is training and supporting a new generation of scholar-practitioners through the US Army's Advanced Strategic Planning and Policy Program, a multiyear program that prepares field-grade officers for service as strategic planners.

\section{PHILIP E. TETLOCK, UNIVERSITY OF} PENNSYLVANIA

\section{Can Forecasting Tournaments Pry Open Closed Minds in Domestic and National-Security Policy Debates?}

Philip E. Tetlock was born in Canada and did his undergraduate work at the University of British Columbia and his doctoral work at Yale University (PhD, 1979). He has served on the faculty at the University of Pennsylvania, currently as Annenberg University Professor (appointments in Wharton, psychology, and political science), University of California, Berkeley (Mitchell Endowed Chair in the Haas School), and The Ohio State University (Burt Endowed Chair in psychology and political science). He has also been a Fellow at the Center for Advanced Study in the Behavioral Sciences (Stanford University) and the Russell Sage Foundation.

He has received awards from the American Psychological Association, American Political Science Association, American Association for the Advancement of Science, International Society of Political Psychology, American Academy of Arts and Sciences, and the National Academy of Sciences. A prolific author, he has published roughly 200 articles in peer-refereed journals and edited or written 10 books.

His research programs have explored a variety of topics, including the challenges of assessing "good judgment" in both laboratory and real-world settings as well as the criteria that social scientists use in judging judgment and drawing normative conclusions about bias and error.

\section{DANIEL J. TICHENOR, UNIVERSITY OF OREGON}

Democracy's Shadow: Undocumented Immigrants and the Quest for Inclusion

Daniel J. Tichenor is the Philip H. Knight Chair of Social Science and Senior Scholar at the Wayne Morse Center for Law and Politics at the University of Oregon. He has published extensively on immigration politics and policy, US political institutions, social movements, civil liberties, and democratic citizenship. His book Dividing Lines: The Politics of Immigration Control in America (Princeton University Press) 
won the Gladys M. Kammerer Award for the best book in American national policy. He has been a faculty scholar at the Center for the Study of Democratic Politics at Princeton University, Research Fellow in Governmental Studies at the Brookings Institution, Abba P. Schwartz Fellow in Immigration and Refugee Policy at the John F. Kennedy Presidential Library, and a research scholar at the Eagleton Institute of Politics at Rutgers University. A recognized teacher, mentor, and speaker, Tichenor regularly gives public lectures and has testified and provided expert briefings to Congress on immigration policy and immigrant integration.
LYNN VAVRECK, UNIVERSITY OF

CALIFORNIA, LOS ANGELES

Dark Money, Super PAC Advertising, and Democracy

Lynn Vavreck is a professor of political science and communication studies at UCLA and a contributing columnist to The Upshot at the New York Times. She teaches courses on and writes about campaigns, elections, and public opinion. Vavreck has published four books, including The Message Matters, which Stanley Greenberg called "required reading" for presidential candidates, and The Gamble, described by Nate Silver as the "definitive account" of the 2012 election. Her research on survey methods, sampling, and the effects of campaigns has been supported by grants from the National Science Foundation. The American Political Science Association recognized her with an award for her research on the rapid decay of the effects of political advertising. Vavreck has served on the advisory boards of the British and American National Election Studies and is the co-founder of the Cooperative Campaign Analysis Project. She holds a PhD in political science from the University of Rochester and held previous appointments at Princeton University, Dartmouth College, and The White House. In 2014, she hosted Hillary Clinton at UCLA's Luskin Lecture on Thought Leadership.

\section{Keep PS Informed}

Share your news and announcements with PS and our readers. Let us know about your new appointment, activity, event, or award. Visit www.apsanet.org/ps and click the "People in Political Science" link to submit your news. E-mail any questions or comments to $P S$ editorial assistant Drew Meadows at dmeadows@apsanet.org. 